Uniwersytet Humanistyczno-Przyrodniczy

im. Jana Długosza w Częstochowie

violetta.ajd@gmail.com

\title{
CHREMATONIMIA JASNEJ GÓRY I JEJ UWARUNKOWANIA KULTUROWE
}

Słow a te maty c zne: chrematonim, hagionim, ideonim, patrocinium, teonim

Tematem szkicu są nazwy własne różnych obiektów znajdujących się w obrębie zespołu klasztornego zakonu paulinów, zlokalizowanego na Jasnej Górze w Częstochowie. Badane nomina propria odnoszą się do denotatów, które obejmują elementy zabudowy zewnętrznej (bazylika, bastiony, bramy, muzea, budynki, dzwony, place) oraz wewnętrznej (kruchty, kaplice, sale), a ponadto do takich wytworów sztuki, jak: ołtarze główne i boczne, rzeźby, obrazy ścienne i sztalugowe, cykle polichromii na malowidłach ściennych i sklepiennych oraz medalionach. Pominięto natomiast onimy dzieł sztuki stanowiących ekspozycje stałe lub zmienne, zlokalizowane $\mathrm{w}$ różnych budynkach kompleksu jasnogórskiego, w tym bogate zbiory Biblioteki Jasnogórskiej i Skarbca.

W analizie onomastyczno-kulturowej przyjęto perspektywę diachroniczną, co pozwoliło na uwzględnienie pierwotnych nazw niektórych obiektów. Przegląd badanego nazewnictwa uporządkowany został według typu obiektów, do których się odnosi.

\section{KOŚCIÓE}

Początki klasztoru sięgają 1382 r., kiedy to książę Władysław Opolczyk sprowadził paulinów z Węgier do dawnego kościoła parafialnego na mocy dekretu książęcego z 9 sierpnia tego roku oraz ufundował klasztor. Nazwa Jasna Góra (łac. Clarus Mons) została nadana klasztorowi przez węgierskich paulinów na pamiątkę macierzystego klasztoru św. Wawrzyńca na Jasnej Górze w Budzie.

Główną część zespołu klasztornego stanowi bazylika (tę rangę świątynia ma od 1906 r.) pw. Znalezienia Krzyża Świętego i Narodzenia Najświętszej Maryi Panny. Pierwszy kościół parafialny (drewniany, jednonawowy) wsi Stara Częstochowa ${ }^{1}$

${ }^{1}$ Częstochowa powstała z połączenia Starej i Nowej Częstochowy (dawnej Częstochówki) 19 sierpnia 1826 r. (Braun 1977: 68). 
pw. NPM Dziewicy i Rodzicielki powstał około połowy XIII w. Na jego miejscu w latach 1425-1430 wzniesiono drugi (murowany z kamienia), przekształcając go w świątynię trójnawową. Trzeci, późnogotycki kościół pw. Świętego Krzyża i NPM, powstał z wykorzystaniem dawnego budynku jako prezbiterium (konsekrowany w 1463 r.). Bazylika jasnogórska, której układ przestrzenny zmieniał się na przestrzeni wieków, obejmuje obecnie: prezbiterium, nawę główną, dwie nawy boczne, cztery kaplice, kruchtę, zakrystię oraz krypty grobowe (Rozanow, Smulikowska 2009: 24-25).

\section{BASTIONY I BRAMY}

Jasna Góra pełniła w przeszłości także funkcję fortecy, utworzonej około $1620 \mathrm{r}$. na polecenie Zygmunta III Wazy i ukończonej staraniem Władysława IV, później powiększonej, obudowanej murami. W $1813 \mathrm{r}$. pozbawiona została funkcji obronnej. Forteca Jasnogórska ${ }^{2}$ stanowiła czworokątną twierdzę z charakterystycznymi bastionami na ostrożach, otoczoną gotycką fosą i wałami ziemnymi. Twierdza wytrzymała trzy oblężenia: Szwedów w 1655 r., Rosjan w 1771 r. i Austriaków w 1809 r.

Na obwarowania twierdzy Fortalitium Marianum (inaczej Twierdza Maryjna; tak nazwał twierdzę jasnogórską w 1639 r. król Władysław IV Waza) składały się bastiony i bramy, które stanowią trwały element zabudowy zespołu klasztornego, istniejący również współcześnie. Fortyfikacje bastionowe Twierdzy Maryjnej tworzą cztery bastiony (Rozanow, Smulikowska 2009: 169-173): północno-wschodni pw. Świętej Trójcy (od nazwiska fundatorów zwany też bastionem ${ }^{3}$ Szaniawskich), południowo-zachodni pw. św. Barbary (od nazwiska fundatorów zwany bastionem Lubomirskich), północno-zachodni pw. NPM (zwany też św. Rocha, a od nazwiska fundatorów bastionem Morsztynów), południowo-wschodni pw. św. Jakuba (tzw. Królewski, od nazwiska fundatorów zwany bastionem Potockich, a od znajdującego się tam pomnika — bastionem o. Kordeckiego).

Zespół bramny (Rozanow, Smulikowska 2009: 173-176, 214) powstawał od lat dwudziestych XVII w. do drugiej połowy XVIII w.; przekształcany był w ciagu XIX i XX w. Składa się z czterech bram i łączących je murów. Są to: zewnętrzna brama Lubomirskich (ufundowana przez podkomorzego koronnego Jerzego Dominika Lubomirskiego, wojewodę krakowskiego, starostę olsztyńskiego, wzniesiona w latach 1722-1723); ulokowana za nią brama Stanisława Augusta (od imion króla Stanisława Augusta Poniatowskiego, wzniesiona w 1767 r. z okazji jego wizyty, która $\mathrm{w}$ rezultacie się nie odbyła; następnie zrujnowana i zrekonstruowana w po-

\footnotetext{
${ }^{2}$ http://www.jasnagora.com/nastronach_opracowanie.php?ID=23\&Strona=5 (dostęp 25 VII 2016).

3 Nazw gatunkowych nie włączono do nazwy właściwej (Badyda 2011: 37).
} 
łowie lat pięćdziesiątych XX w. jako brama pw. MB Zwycięskiej); trzecia to brama MB Bolesnej (wzniesiona w latach 1631-1641, przekształcona w 1723 r., restaurowana w 1906 r.); czwarta to brama Wałowa, tzw. Jagiellońska//Jagiellonów (wzniesiona w latach 1631-1641, uzupełniona w 1723 r., restaurowana w 1906 r.). Przy bastionie południowo-zachodnim położona jest brama Wałowa im. Jana Pawła II, tzw. Papieska (przebudowana w 1987 r.), która powstała z dawnej bramy przejazdowej. 9 grudnia 2016 r. otwarto na Jasnej Górze bramę Miłosierdzia (trzecia w kolejności od głównej bramy Lubomirskich).

\section{MUZEA}

Na terenie kompleksu klasztornego funkcjonują cztery muzea (Rozanow i Smulikowska 2009: 56-57, 164, 167): Muzeum 600-lecia Jasnej Góry (otwarte od 1982 r. w budynku drukarni, pochodzącym z pierwszej ćwierci XVIII w., do którego wchodzi się z dziedzińca klasztornego; prezentuje działalność kulturalno-artystyczną paulinów); Arsenat Jasnogórski (wzniesiony w latach 1660-1680, czynny do 1812 r.; na parterze mieści się sala dawnej zbrojowni, która obecnie przeznaczona jest na ekspozycje zmienne); Skarbiec (zbudowany w latach 1649-1651 nad zakrystią; wejście z wałów od strony wschodniej); Skarbiec Pamięci Narodu im. o. Augustyna Kordeckiego (od 2006 r.; zlokalizowany we wnętrzu wałowego bastionu św. Rocha).

Funkcje muzealne pełnią także: sala Sakramentu Pokuty (dawniej sala Maryjna), która znajduje się w budynku sąsiadującym od zachodu z bramą Wałową, do lat pięćdziesiątych ubiegłego wieku odgrywała rolę spowiednicy, pełni obecnie funkcję sali wystawowej ze zmiennymi ekspozycjami (Rozanow, Smulikowska 2009: 164-165, 167); sala Rycerska ${ }^{4}$ (dawniej sala Dysput Teologicznych), zbudowana w latach 1647-1649 w południowym skrzydle klasztoru jako pomieszczenie reprezentacyjne (była miejscem uroczystości klasztornych), stanowiące początkowo osobnym budynek, położony równolegle do Kaplicy Matki Bożej i połączony z nią przejściami na obu kondygnacjach; sala im. o. A. Kordeckiego (poświęcona przez papieża św. Jana Pawła II podczas pobytu na Jasnej Górze 4 czerwca 1997 r.), która znajduje się w przejściu pomiędzy bramą wjazdową a dziedzińcem; sala Papieska (poświęcona w 1997 r. przez Jana Pawła II), zlokalizowana pod jasnogórskimi wałami.

\footnotetext{
${ }^{4}$ http://www.jasnagora.com/nastronach_opracowanie.php?ID=23\&Strona=1 (dostęp 25 VII 2016).
} 


\section{INNE BUDOWLE I OBIEKTY}

Przy dziedzińcu gospodarczym znajduje się kilka obiektów (Rozanow, Smulikowska 2009: 162-164): Domy Muzykantów (budynek wzniesiony w latach 1620-1658, przeznaczony pierwotnie na mieszkanie dla służby klasztornej, m.in. kapeli jasnogórskiej, częściowo dla załogi fortecznej i komendanta; obecnie na parterze budynku mieszczą się toalety i punkt informacyjny); Apteka (utworzona w 1639 r. przez prowincjała o. Paulina Kłodawskiego na potrzeby klasztoru i pielgrzymów, dawniej mieściło się tu laboratorium farmaceutyczne, czynne do 1864 r.) i tzw. Pokoje Królewskie (ulokowane w tym samym budynku na piętrze, przeznaczone niegdyś dla dostojników, m.in. królów, gdyż reguła zakonu paulinów zabraniała przebywać osobom świeckim na terenie klasztoru klauzurowego); Stary Świat (zachodnie skrzydło klasztoru, tzw. mały klasztor, wzniesiony przed 1633 r., przebudowany po połowie XVII w. - jednopiętrowy budynek połączony skrzydłami z basztami narożnymi skrzydła zachodniego budynku głównego klasztoru).

Ponadto wymienić należy: Krużganek Eucharystyczny, tzw. Wieczernik (ulokowany obok bazyliki, który powstał na miejscu dawnego cmentarza); Domek Odźwiernego (dawny budynek straży fortecznej z drugiej połowy XVII w., przebudowany w XIX w., wtopiony narożnikiem w południowo-wschodnią bramę Wałową); Bibliotekę Jasnogórska (budynek z początku XVIII w., umiejscowiony ponad wielkim refektarzem w skrzydle zachodnim klasztoru ${ }^{5}$ ) - Starq (dawne definitorium) i Nowa (dawniej sala posiedzeń kapituły zakonnej) (Rozanow, Smulikowska 2009: 114-117).

\section{KAPLICE}

W rozbudowanym zespole klasztornym Jasnej Góry znajduje się dziewięć kaplic, z czego cztery umiejscowione są w samej bazylice (Rozanow, Smulikowska 2009: 39-52): pw. Świętych Relikwii (wzniesiona w latach 1626-1628 jako kaplica św. Filipa Nereusza; w 1666 r. przebudowana na kaplicę pw. Świętych Relikwii; w latach 1751-1754 przekształcona staraniem księcia S. W. Jabłonowskiego na kaplicę grobową Jabłonowskich; w latach 1875-1927 przechowywany był tu obraz Matki Boskiej Kodeńskiej i w tym czasie funkcjonowała jako kaplica pw. Matki Boskiej Kodeńskiej), pw. Aniołów Stróżów, zwana też Świętych Aniołów Stróżów // Najświętszego Serca Pana Jezusa // Jabłonowskich (powstała w latach 1751-1754), pw. św. Pawła Pierwszego Pustelnika // św. Pawła Eremity // Denhoffów (wzniesiona w 1382 r. w celu pomieszczenia relikwii św. Pawła

\footnotetext{
${ }^{5}$ http://www.niedziela.pl/artykul/2480/Biblioteka-Jasnogorska (dostęp 25 VII 2016).
} 
Eremity, przyniesionej przez paulinów z konwentu św. Wawrzyńca koło Budy na Węgrzech, ufundowana przez Kaspra Denhoffa, wojewodę sieradzkiego i senatora Rzeczypospolitej, z przeznaczeniem na mauzoleum rodziny Denhoffów; budowana etapami przez kolejnych członków rodu do 1676 r., restaurowana w latach 1818-1819), pw. św. Antoniego Padewskiego (wzmianka o niej pochodzi z 1652 r., niszczona przez pożary, restaurowana w 1690, 1857 r. oraz w latach 1990-1991).

Pomiędzy kościołem a południowym skrzydłem klasztoru usytuowana jest kaplica Cudownego Obrazu (Cudownego Obrazu Matki Boskiej // Matki Boskiej Częstochowskiej // Matki Boskiej Jasnogórskiej; w pierwszej połowie XVII w. zwana Królewska Komnata Marii) (Rozanow, Smulikowska 2009: 65-68).

Pozostałe obiekty sakralne tego typu to kaplice: pw. Najświętszego Sakramentu (Rozanow, Smulikowska 2009: 69), ulokowana na piętrze ponad przedsionkiem do kaplicy Cudownego Obrazu; powstała na miejscu dawnego chóru zakonnego - kapitularza z pierwszej połowy XV w., przebudowana około połowy XVI w., w drugiej połowie XVII w. zamieniona w kaplicę pw. św. Józefa//pw. Wieczystej Adoracji Najświętszego Sakramentu; Różańcowa (Rozanow, Smulikowska 2009: 114), umiejscowiona w południowym skrzydle klasztoru, obok lewej nawy głównej kaplicy Cudownego Obrazu, dawniej refektarz mniejszy, mieści się w przyziemiu skrzydła południowego, powstała w pierwszej połowie XVII w.; Sakramentu Pokuty - zlokalizowana w dawnej Sali Maryjnej, usytuowanej tuż przy bramie wejściowej na Jasną Górę; Pamięci Narodu im. o. Kordeckiego — znajduje się w dawnej dzwonnicy, powstałej w XVII w., konsekrowanej jako kaplica 3 maja 1989 r., położona nad południowo-wschodnią częścią prezbiterium bazyliki, pełni funkcję mauzoleum — na wszystkich ścianach w oszklonych niszach umieszczono urny z prochami Polaków poległych w obronie ojczyzny.

\section{OETARZE}

W częstochowskim sanktuarium znajduje się 21 ołtarzy, z czego 12 zlokalizowanych jest w bazylice, są to: ołtarz główny: Wielki Ottarz//Wniebowzięcia i Koronacji NPM oraz ołtarze boczne - w nawie prawej: św. Anny, św. Józefa z Dzieciatkiem (pierwotnie św. Łukasza), Pokłon Mędrców ze Wschodu (dawniej św. Franciszka Ksawerego), św. Kazimierza; w nawie lewej: św. Joachima (również pw. Matki Boskiej Różańcowej), św. Jadwigi Królowej (wcześniej św. Jana Nepomucena), św. Augustyna (dawniej św. Stanisława Biskupa i Męczennika), Bożego Narodzenia, św. Maksymiliana Marii Kolbego (dawniej św. Zyty); w kaplicach: św. Antoniego Padewskiego (w kaplicy św. Antoniego Padewskiego), Chrystusa (w kaplicy św. Aniołów Stróżów), św. Walentego (w kaplicy Świętych Relikwii; pierwszy ołtarz z 1677 r. pw. św. Barbary). 
Sześć ołtarzy umiejscowionych jest w kaplicy Cudownego Obrazu: ołtarz główny pw. Matki Boskiej (ufundowany w 1650 r. przez Jerzego Ossolińskiego) oraz ołtarze boczne pw.: MB Bolesnej (północny), Chrystusa Ukrzyżowanego (południowy), Ofiarowania Matki Boskiej (za pierwszym filarem, licząc od wschodu, po stronie północnej), Narodzenia MB (za pierwszym filarem, licząc od wschodu, po stronie południowej), Nawiedzenia św. Elżbiety (za drugim filarem, licząc od wschodu, po stronie północnej), Zwiastowania NMP (za drugim filarem, licząc od wschodu, po stronie południowej).

Ponadto wśród chrematonimów odnoszących się do jasnogórskich ołtarzy wymienić należy jeszcze onimy: św. Wacława (w zakrystii) oraz św. Jana Ewangelisty (w Sali Rycerskiej), a także utworzony na murach obronnych od strony parków ołtarz Przed Szczytem.

\section{OBRAZY, CYKLE POLICHROMII (MALOWIDŁA ŚCIENNE I SKLEPIENNE ORAZ MEDALIONY)}

W kościele do najciekawszych dzieł sztuki malarskiej należą:

a) w przęsłach prezbiterium (malowidła sklepienne oraz medaliony powstałe w XVII w., restaurowane w latach 1910-1916) cykl pt. Historia, chwała i triumf Krzyża Świętego (Rozanow, Smulikowska 2009: 30-31), np.: Krzyż wsparty na globie ziemskim podtrzymywany przez anioła, Grzech pierworodny z wyrastajacym z Drzewa Wiadomości Krzyżem, Adoracja Krzyża przez reprezentantów różnych ludów, Znalezienie i Podwyższenie Krzyża Świętego przez cesarza Herakliusza, Rozproszenie nieprzyjaciót Krzyża, Upokorzenie nieprzyjaciół Wiary liżacych ziemię;

b) w nawie głównej i bocznej cykl polichromii (malowidła i medaliony) pt. Chwała Najświętszej Pannie Marii, zobrazowana w cudach Matki Boskiej, również Częstochowskiej, oparta na oryginalnych zapisach w Księdze cudów, dominuje tu symbolika maryjna (Rozanow i Smulikowska 2009: 31), np.: NPM Niepokalanie Poczęta na globie ziemskim, Przywrócenie wzroku ślepemu, Uzdrowienie chorych, NPM Łaskawa, Uratowanie górników zasypanych w kopalni srebra w Olkuszu, NPM pogromicielka Szwedów, Dziękczynienie króla Jana III z matżonkq Maria Kazimiera za zwycięstwo wiedeńskie w 1683 przed NPM z Dzieciatkiem, Uzdrowienie opętanych, Wyzwolenie więźniów;

c) w przęsłach nawy głównej cykl hagiograficzny — postacie świętych i błogosławionych, m.in. patronów polskich oraz zakonu paulinów (Rozanow, Smulikowska 2009: 31-32), np.: Święty Józef, Święty Antoni Opat, Święty Hieronim, Święty Karol Boromeusz, Święty Jan Chrzciciel, Święty Stefan król Węgier, Święty Wawrzyniec, Święta Maria Magdalena, Święta Maria Egipcjanka, Święta Pulcheria, Święta Helena, Btogosławiona Kinga, Btogostawiona Salomea, Btogostawiony Stanistaw Kostka, Błogostawiony Stanisław z Oporowa, Dawid z harfa; 
d) w nawie północnej malowidła z symboliką maryjną (Rozanow, Smulikowska 2009: 32), m.in.: NPM uwalniajaca dusze z ogni czyśćcowych, wstęujaca na szczyt góry po wykutych stopniach, NPM wiodqca pielgrzymów ku widocznemu na wzgórzu klasztorowi jasnogórskiemu, NPM ożywiajaca prochy zmartych; NPM nalewajaca poranionemu balsam $w$ rany, NPM jako Królowa upokarzajaca przed swym ołtarzem nieprzyjaciół, Gołabka Pokoju i gałazka oliwna;

e) w nawie południowej przedstawienia głównie o tematyce militarnej, sceny z ksiąg cudów i kronik jasnogórskich, np.: Wieża warowna z zawieszonymi tarczami, Anioł osłaniajacy glob ziemski tarcza z wizerunkiem Matki Boskiej Częstochowskiej, NPM jako świattość nocy na tle dwunastu gwiazd, NPM osłaniajaca płaszczem klasztor jasnogórski ostrzeliwany przez wroga, Wizerunek MB Częstochowskiej ukazujacy się wśród fal rozbitkom na znak ocalenia (Rozanow, Smulikowska 2009: 32-33);

f) na ścianach podchórzy (Rozanow, Smulikowska 2009: 33): Święty Pawet Eremita w pustelni, Święty Antoni Opat udajacy się do klasztoru, Wizja bł. Stanisława z Oporowa, Jezus, Wizja św. Antoniego Padewskiego z NPM z Dzieciatkiem w obtokach;

g) przy ołtarzu głównym znajdują się obrazy: NPM, Trójcy Świętej, Ukrzyżowania, Świętych Piotra i Pawta, Wszystkich Świętych; przy ołtarzach bocznych: Święty Józef z Dzieciatkiem, Święta Anna Samotrzeć, Święty Maksymilian Maria Kolbe, Święty Augustyn z pokonanq Herezja u stóp, Święty Kazimierz, Apoteoza św. Jana Nepomucena, Niewiasty jerozolimskie, Pokłon Mędrców ze Wschodu, Pokłon pasterzy, Pokłon Trzech Króli (Rozanow, Smulikowska 2009: 35-36).

Również kaplice bazyliki są bogato ozdobione dziełami sztuki malarskiej:

a) w kaplicy św. Pawła Eremity znajdują się medaliony (Rozanow, Smulikowska 2009: 43-46), m.in.: Święty Pawet przy pieczarze góry Kolzim odziany przez anioła $w$ tunike palmowa; Spotkanie $i$ wspólny posiłek św. Pawła Eremity z Antonim Opatem; Śmierć św. Pawła; obrazy: Święty Zygmunt, Święta Tekla, Święta Teresa z Avila, Święty Maurycy, Święta Pulcheria, Święta Helena; Apoteoza św. Pawta Eremity, Święty Hieronim przy pisaniu żywota św. Pawła, Święty Antoni Opat relacjonujacy swoja wizje przekazania z Nieba palmowej tuniki eremity;

b) w kaplicy Aniołów Stróżów medaliony wyrażające Chwałę Krzyża i Mękę Chrystusa (Rozanow, Smulikowska 2009: 49-51): Waż miedziany, Chrystus podejmujacy Ofiarę Krzyża, Chrystus niosacy krzyż na Golgotę, Chrystus Zwycięski z krzyżem, zbawiajacy pogan; obraz: Siedmiu św. Archaniołów adorujacych Trójcę Święta;

c) w kaplicy pw. św. Antoniego Padewskiego malowidła sklepienne przedstawiające sceny z żywota św. Antoniego: Uzdrowienie chorych, Spotkanie świętego z królem, Chleb św. Antoniego; w ościeżach okien: Święty na tle klasztoru, Dysputa z królem, Powitanie braci zakonnych; obrazy: Wizja św. Antoniego Padewskiego z Dzieciatkiem Jezus w ramionach, NMP w obłokach, Cud św. Antoniego z osłem;

d) w kaplicy Świętych Relikwii (Rozanow, Smulikowska 2009: 41): Święte Apolonia i Agnieszka, Święta Tekla, Święty Walenty, Święty Juda Tadeusz; 
e) w kaplicy pw. Najświętszego Sakramentu: Wizja bł. Euzebiusza, Lata dziecięce Chrystusa i Ofiarowanie Chrystusa ws światyni (XVII w.).

W kaplicy Cudownego Obrazu centralne miejsce zajmuje obraz MB z Dzieciatkiem//MB Częstochowska. Odwrocie Cudownego Obrazu (Rozanow, Smulikowska 2009: 84-86) zakrywa malowidło Mensa Mariana (Stót Maryjny) z około 1705 r., które przedstawia cztery etapy wędrówek obrazu, zatytułowane: Rozgromienie floty nieprzyjacielskiej, Modlitwa księcia Władysława Opolczyka przed obrazem w kaplicy zamkowej w Betzie, Przekazanie paulinom obrazu przez księcia Władysława Opolczyka, Wskrzeszenie przed obrazem na Jasnej Górze matki z dwojgiem dzieci w roku 1540, Oblężenie Jasnej Góry przez Szwedów w 1655 roku.

Ponadto wymienić można obraz pt. Komunia Jagiellonów, malowidła sklepienne i ścienne (Rozanow i Smulikowska 2009: 75-78), m.in.: Zwiastowanie, Ucieczka do Egiptu, Boże Narodzenie, Pokłon Pasterzy, Pokłon Trzech Króli, Ofiarowanie w światyni, Anioł nakazujacy Józefowi ucieczkę do Egiptu, Tronujaca Najświętsza Panna Maria z Dzieciatkiem, Apokaliptyczna Księga Siedmiu Pieczęci, Anioł w obłokach, Męczeństwo Wilgefortis, Najświętsza Panna Maria Pogromczyni Herezji, Oblężenie Jasnej Góry przez Szwedów w 1655 i odwrót wojsk spod twierdzy, Najświętsza Panna Maria Królowa Nieba i Ziemi z Dzieciatkiem Salvatorem Mundi oraz obrazy sztalugowe (Rozanow, Smulikowska 2009: 109-110): Dzieciństwo Chrystusa (z początku XVII w.; przedstawia NMP karmiącą Dzieciątko w asyście Jana Chrzciciela z barankiem i usługujących aniołków), Ofiarowanie Chrystusa $w$ światyni (z pierwszej połowy XVII w.; przedstawia NMP i św. Józefa pokazujących prorokini Annie Dzieciątko, błogosławiące Jana Chrzciciela), Estera przed Ahaswerem (sprzed połowy XVII w.; przedstawia Esterę padającą na kolana przed Ahaswerem w otoczeniu dworzan).

Na sklepieniu nawy głównej w medalionach umieszczono cykl 28 malowideł patriarchów, apostołów, ewangelistów, ojców i doktorów Kościoła, świętych i błogosławionych patronów Polski (Rozanow, Smulikowska 2009: 78-79, Bar 1999), m.in.: święci Stanisław Kostka i Kazimierz Królewicz, apostołowie Juda Tadeusz i Jan Ewangelista, Paweł i Piotr, święci Kinga, Wojciech, Stanisław bp, Jadwiga Ślaska, ewangeliści Jan i Łukasz, Święty Jacek Odrowąz, Blogosławiony Szymon z Lipnicy, apostołowie: Filip i Bartłomiej, Andrzej i Szymon, święci i błogosławieni: Jolanta, Wincenty Kadtubek, Maciej Apostol, Salomea; Ambroży, Augustyn, Bonawentura, Anzelm, Bernard z Clairvaux, Hieronim, Tomasz z Akwinu, Albert Wielki.

Przy ołtarzach bocznych (Rozanow, Smulikowska 2009: 101-103) znajdują się obrazy - druga para: Wprowadzenie NPM do Światyni, Narodzenie NPM; trzecia para: Nawiedzenie NPM, Zwiastowanie.

Ikonografię kaplicy Cudownego Obrazu dopełniają stacje drogi krzyżowej (14), malowane na deskach.

Ściany kruchty zdobi obraz Chrystus ukrzyżowany oraz polichromia zatytułowana: Wniebowzięcie i Koronacja NPM w otoczeniu świętych oraz Ojców 
i Doktorów Kościoła, a zakrystię 12 malowideł, m.in.: Porażenie Heliodora w światyni jerozolimskiej przed ottarzem z Arka Przymierza, Personifikacja Sprawiedliwości i anioł ukazujacy szalę niebiańska, Porażenie Heliodora $w$ światyni jerozolimskiej, Salomon z orszakiem przynoszacy dary do światyni jerozolimskiej, Postać w ciemnej chuście kuszona przez węża.

Wystrój wzbogacają nadto malowidła na płycinach malowanych komód. Są to: cykl 12 obrazów pt. Droga życia wiecznego oraz cykl obrazów z życia eremitów i pokutnic: Święty Romuald w pustelni, Męczeństwo św. Dymfny, Święty Pafnucy błogosławiacy Taidę rozpoczynajaca pokute, Ostatnia komunia Marii Egipcjanki, Kuszenie św. Antoniego, Święta Sofronia pustelnica, Święty Martynian na skalnej wyspie.

W przedsionku pomiędzy kościołem a kaplicą Cudownego Obrazu znajduje się obraz Cud wskrzeszenia zmartej matki z dwoma synami.

Znajdujące się w przedsionku Sali Rycerskiej malowidła ścienne przedstawiają dzieje Jerzego Martinuzziego, paulina i kardynała Węgier: Wstapienie do zakonu paulinów, Biskup i skarbnik koronny Węgier, Nominacja na kardynała przez papieża Juliusza II, Zdradzieckie zamordowanie kardynała w 1551 r. przez wynajętych innowierczych zabójców, Msza żałobna przy zwłokach Martinuzziego.

W budynku klasztoru wskazać można:

a) w środkowej celi klasztoru malowidło ścienne Chrystus ukrzyżowany z Matka Boska i św. Janem Ewangelista;

b) na korytarzu: Fundacja klasztoru przez Władysława księcia opolskiego, Napad obrazoburców husyckich na klasztor jasnogórski, Dziękczynienie królewicza Władysława IV za zwycięstwo pod Chocimiem w 1621 r., Oblężenie Jasnej Góry przez Szwedów w 1655 r., Król Jan Kazimierz w 1661 r. przyjmujacy na Jasnej Górze hołd Kozaków zaporoskich, Ślub Michała Korybuta Wiśniowieckiego z księżniczka austriacka Eleonorq, Uroczyste przewiezienie z Rzymu na Jasna Górę w 1681 r. relikwii męczenników Honorata i Kandyda, na jubileusz 300-lecia klasztoru, Jan III Sobieski z synami w 1683 r. na Jasnej Górze przed wyprawq wiedeńska, Uroczyste wprowadzenie obrazu Matki Boskiej Częstochowskiej do odbudowanego po pożarze kościoła jasnogórskiego; portrety św. Stefana i św. Władysława oraz poczty portretowe: Władcy polscy od Lecha do Stanisława Augusta, Władcy wegierscy od Korwina do cesarza Józefa II;

c) w refektarzu i korytarzu klasztoru malowidła ścienne: Apoteoza św. Tekli, Apoteoza św. Pawła, Miłosierdzie, Czystość, Pokój, Postuszeństwo, Ubóstwo, Pokora, Pokuta, Wstrzemięźliwość, Szczęście Publiczne (personifikacja cnót), Matka Boska Bolesna, Anioł broniacy wstępu na progu Świętej Bramy, Chrystus Zbawca świata, obrazy maryjne w płycinach szaf bocznych, m.in.: Matka Boża — Dziewica dziewic, Matka pięknej miłości, Matka pięknej nadziei, Matka uczczona, Źródło życia, Okręt kupiecki, Zdrój zapieczętowany, Studnia wody żywej, Potok miodu i masła, Zwierciadło bez skazy, Tron Salomona, Niewiasta przyodziana w słońce, Cześć ludu naszego, Miasto mocy, Tarcza majacych w Niej nadzieje,, Wojska uszykowane 
porzadnie, Raj rozkoszy, Krzak płonqcy niespalony, Namiot przymierza, Różdżka Jessego, Gwiazda zaranna, Jutrzenka wschodzaca, Najwyższe przebłaganie, Brama niebios;

d) w przedsionku kaplicy Różańcowej malowidła ścienne: Zwiastowanie, Nawiedzenie św. Elżbiety, Wniebowzięcie, Święty Kazimierz Jagiellończyk na katafalku oraz obraz Adoracja NPM Niepokalanie Poczętej z Dzieciatkiem przez świętych dominikańskich.

W Muzeum 600-lecia Jasnej Góry do ciekawych ekspozycji należą obrazy postaci świętych paulińskich: Pawła Pierwszego Pustelnika i Antoniego Opata; cykl eremicki obrazów z XVII w., przedstawiających św. Andrzeja Świerada oraz $s ́ w$. Benedykta (płótna z XVII w., ilustrujące m.in. fundację klasztoru jasnogórskiego przez Władysława Opolczyka, zatwierdzenie zakonu paulinów przez papieża Urbana IV oraz męczeństwo paulinów na Węgrzech w czasie najazdu tureckiego w 1526 r.); portrety prowincjałów i generałów zakonu malowane w pracowni jasnogórskiej: o. K. Biedrzychowskiego, o. A. Gołdonowskiego, o. Augustyna Kordeckiego, o. Tobiasza Czechowicza.

Na uwagę zasługuje również Golgota Jasnogórska - 18 obrazów Jerzego Dudy-Gracza ściśle związanych z Jasną Górą, dar wotywny artysty; cykl malowideł w 2001 r. umieszczony został na piętrze krużganku: Jezus na śmierć skazany, Jezus bierze krzyż, Jezus po raz pierwszy upada, Jezus spotyka Maryję, Przypowieść o Cyrenejczyku, Ulica św. Weroniki, Jezus po raz drugi upada, Jezus pociesza płaczace kobiety, Jezus po raz trzeci upada, Jezus do naga odarty, Jezus do krzyża przybity, Modlitwa miejska, Jezus na krzyżu umiera, Jezus z krzyża zdjęty, Jezus do grobu złożony, Jezus zmartwychwstaje, Jezus ukazuje się apostołom, Jezus ukazuje się w Galilei, Wniebowstapienie do Częstochowy.

\section{RZEŹBY I FIGURY}

Wśród chrematonimii zespołu klasztornego Jasnej Góry wyróżnić można licznie reprezentowane nazwy figur i rzeźb. Są to:

- w kościele przy kolumnach ołtarza głównego figury czterech Ewangelistów: św. Łukasza, św. Jana, św. Marka, św. Mateusza; kompozycja rzeźbiarska Wniebowzięcie i Koronacja NPM;

— u zwieńczenia ołtarza: Trójca Święta koronujaca Marię;

— przy ołtarzach bocznych pierwsza para (lewy): Bóg Ojciec Stwórca Świata, Święty Joachim prowadzacy Marię na naukę do światyni pod opieka archaniota Gabriela, Święty Zygmunt, Arcykapłan Aaron; (prawy): Maria Niepokalanie poczęta; rzeźba: Święta Anna z Maryja, figury: Święta Anna z blogosławiacym Chrystusem —Zbawca Świata, Zachariasz, Symeon; druga para (lewy): Święty Jan Nepoтисел; 
— przy ołtarzach w nawach bocznych figury: Święty Stanisław wskrzeszajacy rycerza Piotra, Święty Franciszek udzielajacy chrztu Indianinowi, figury świętych Grzegorza i Ambrożego;

— przy ołtarzu pw. Bożego Narodzenia (przęsło II) figura: Archanioła Gabriela;

- w kaplicy pw. Świętych Relikwii figury Caritas i Justitia oraz rzeźba Chrystusa: Ecce Homo; po bokach ołtarza w kaplicy pw. św. Antoniego Padewskiego figury św. Joachima i św. Anny;

- w kaplicy Cudownego Obrazu rzeźba Pieta; przy ołtarzu głównym: Wniebowzięcie i Koronacja NPM i płyciny ze scenami z żywota NPM: Zwiastowanie i Nawiedzenie; na zwieńczeniu ołtarza: NMP Apokaliptyczna z Dzieciqtkiem; ponadto srebrne figury: św. Pawła Pierwszego Pustelnika, św. Kazimierza Jagiellończyka;

— w zakrystii rzeźba: Chrystus Zmartwychwstaty adorowany przez dwóch aniołów;

— w kruchcie rzeźby NPM Apokaliptycznej z Dzieciatkiem, św. Michała Archanioła oraz figury św. Pawła Eremity, św. Antoniego Opata;

— nad wejściem do Wieczernika posag Chrystusa Króla;

- na budynku wieży na narożnikach galerii trzeciej kondygnacji umieszczono cztery kamienne figury: św. św. Pawła Pierwszego Pustelnika, Floriana, Jadwigi Ślaskiej i Kazimierza, a na balustradzie najwyższej kondygnacji cztery miedziane posagi przedstawiające: świętych Augustyna, Wojciecha, Stanisława oraz papieża Leona XIII;

- przy bramie Lubomirskich widoczne są płaskorzeźby: świętych Michała Archanioła, Pawła Pierwszego Pustelnika i Antoniego Opata;

- w otoczeniu twierdzy umiejscowione są kamienne rzeźby: Chrystus Zbawca Świata, NPM, Święty Paweł Eremita, Matka Boska, Święty Antoni Opat, Święty Kazimierz;

— u wylotu wjazdu, przy drodze rzeźba Święty Jan Chrzciciel pod krzyżem;

- w otoczeniu placu umieszczone zostały figury świętych Jana Nepomucena (z 1724 r.) i Prokopa (z drugiej połowy XVIII w.), a na placu Przed Szczytem na kolumnie - figura Matki Boskiej;

- wzdłuż murów w parku klasztornym otaczającym z trzech stron mury sanktuarium (dawne fosy fortecy) zbudowano w latach 1900-1913 według projektu Stefana Szyllera 14 stacji Drogi Krzyżowej; grupy rzeźbiarskie są odlane w brązie i umieszczone na granitowych postumentach z potężnych głazów i polerowanego granitu;

— na placu wokół klasztoru w latach 1989-2005 powstało 20 stacji Drogi różańcowej z 20 tajemnicami różańcowymi. 


\section{POMNIKI}

Wśród monumentów jasnogórskich wymienić należy pomniki: kardynała Stefana Wyszyńskiego z 1997 r. (w pobliżu bramy Lubomirskich), o. Augustyna Kordeckiego z 1859 r. (ulokowany na wałach, w centralnej części bastionu Królewskiego), Jana Pawła II z 1999 r. (na bastionie Świętej Trójcy).

\section{MOZAIKI}

Na uwagę zasługują także dwie mozaiki posadzkowe zatytułowane $M B$ Królowa (przy bramie Lubomirskich) i Adoracja MB Częstochowskiej przez św. św. Pawła Eremitę i Jana Ewangelistę w otoczeniu aniołów (przy budynku apteki).

\section{DZWONY}

Wartość historyczną ma jasnogórski dzwon pw. Jezus Maria z 1544 r. Dwa inne, pw. Maria oraz Pawet, odlane zostały w 1912 r. (Rozanow, Smulikowska 2009: 173).

\section{ODZNACZENIE}

Od 4 czerwca 1979 r. w chrematonimii sanktuarium pojawił się również faleronim Złota Róża - odznaczenie papieskie nadane Cudownemu Wizerunkowi Matki Bożej Jasnogórskiej przez Jana Pawła II.

Zaprezentowane nazewnictwo odnoszące się do poszczególnych obiektów, mieszczących się w obrębie zespołu klasztornego na Jasnej Górze, reprezentuje różne typy chrematonimów o heterogenicznej motywacji kulturowej i rozmaitych strukturach nazewniczych. Charakter opracowania uniemożliwia ich szczegółowy i wyczerpujący opis. Dlatego przedstawiona poniżej tabela stanowi próbę (uproszczonego i niedoskonałego) usystematyzowania uwarunkowań kulturowo-językowych chrematonomastykonu jasnogórskiego sanktuarium.

Określenia różniące się tylko formą językową (gramatyczną) typu brama Jagiellońska//Jagiellonów potraktowano jako warianty językowe tego samego onimu. Jako odrębne jednostki onimiczne uwzględniono natomiast określenia wariantywne (dawne i współczesne) związane z różną motywacją nazw tego samego denotatu, np. kaplica pw. Aniołów Stróżów//pw. Najświętszego Serca Pana Jezusa//Jabłonowskich.

Nawarstwiający się przez wieki chrematonomastykon Jasnej Góry — ściśle połączony z podwójną rolą tego miejsca, które od początku związane było z kultem maryjnym i dodatkowo pełniło funkcje obronne jako Forteca Jasnogórska — obej- 
muje przede wszystkim ideonimy — 441 określeń, w mniejszym stopniu patrocinia — 46 onimów, a także chrematonimy odnoszące się do różnych obiektów (budynków, pomieszczeń itp.) — 42 nazwy oraz faleronim. Wśród nazw dzieł sztuk plastycznych wyraźnie dominuje leksyka mariologiczna i hagiograficzna oraz mieszana, w mniejszym stopniu chrystologiczna, trynitarna i angelistyczna.

Uwzględniając aspekt motywacyjny, analizowane chrematonimy można podzielić zasadniczo na dwie grupy. Pierwszą stanowią nazwy bezpośrednio związane ze sferą sacrum, motywowane głównie przez: teonimy i hagionimy o różnej proweniencji (m.in. osoby Trójcy Świętej, Jezus Chrystus, Maryja, Biblia, święci i błogosławieni, w tym patroni polscy), imiona lub imiona i nazwiska duchownych zasłużonych dla Kościoła, zasłużonych braci zakonu paulinów, a także przełożonych klasztoru jasnogórskiego oraz określenia odapelatywne m.in. związane ze scenami z żywotów świętych i błogosławionych, np. malowidło ścienne Wstapienie do zakonu paulinów z dziejów Jerzego Martinuzziego, paulina i kardynała Węgier; leksykę religijna, np. kaplica pw. Najświętszego Sakramentu czy pw. Świętych Relikwii; metafory i symbole religijne o różnej genezie, zwłaszcza biblijnej, np. obraz Krzew gorejacy, rzeźba Caritas, malowidło ścienne Miłosierdzie.

Do drugiej grupy należą nazwy niezwiązane bezpośrednio ze sferą sacrum, motywowane przez antroponimy (m.in. świeckich fundatorów różnych obiektów w obrębie kompleksu sanktuarium, postaci historycznych, np. kaplica Denhoffów, bastion Szaniawskich, brama Stanisława Augusta), oronim (Jasna Góra), toponimy (np. Betza), etnonimy (np. Szwedzi, Kozacy) oraz nazwy pospolite związane głównie z historią powstania klasztoru, jego dziejami oraz lokalizacją desygnatów na wzgórzu jasnogórskim lub w obrębie kompleksu klasztornego, np. ołtarz Przed Szczytem.

Pod względem budowy językowej wśród badanych onimów wyraźnie dominują nazwy analityczne o charakterze deskryptywno-informacyjnym. Konstrukcje typu frazematycznego nie tylko nazywaja, ale i opisują obiekty, np. rzeźba Święty Joachim prowadzqcy Marię na naukę do światyni pod opiekq archanioła Gabriela, malowidło ścienne Okręt na wzburzonych falach z rozwiniętymi żaglami.

Na uwagę zasługuje występowanie ciąów tematyczno-leksykalnych, a obecność niektórych onimów (teonimów, hagionimów) w obrębie serii umotywowana jest ich wartością konotacyjną. W aktach kreacyjnych ujawniają się przede wszystkim determinanty pozajęzykowe, zwłaszcza ranga denotatu (Cieślikowa 1994: 193-194; Handke 1997: 447).

Nazwy odtopograficzne, wskazujące na naturalne lub urbanistyczne właściwości obiektów w przestrzeni zespołu klasztornego, stanowią nieliczną grupę. Bogato natomiast reprezentowane są nazwy pamiątkowe, na które składają się przede wszystkim ideonimy powstałe od podstaw antroponimicznych i apelatywnych, wskazujących na ważne wydarzenia z historii kraju lub samego klasztoru — nazwy nawiązujące do postaci historycznych, wydarzeń, miejsc, faktów, np. Fundacja 
klasztoru przez Władysława księcia opolskiego, Król Jan Kazimierz w 1661 r. przyjmujacy na Jasnej Górze hołd Kozaków zaporoskich.

Podsumowując, należy zauważyć, że analizowane nazewnictwo jest ściśle powiązane z historią i podwójną rolą jasnogórskiego sanktuarium. Tym samym motywacja kulturowa chrematonomastykonu Jasnej Góry łączy motywację religijną z pamiątkową i topograficzną.

Motywacja leksykalna i kulturowa jasnogórskiego chrematonomastykonu (z liczbą onimów)

\begin{tabular}{|c|c|c|c|c|}
\hline \multirow{2}{*}{$\begin{array}{c}\text { Motywacja kulturowa nazw } \\
\text { z charakterystyką podstaw } \\
\text { leksykalnych }^{6}\end{array}$} & \multicolumn{4}{|c|}{ Typy chrematonimów } \\
\hline & ideonimy & patrocinia $^{7}$ & faleronimy & inne \\
\hline $\begin{array}{l}\text { 1. Święta Trójca } \\
\text { onimy trynitarne } \\
\text { onimy trynitarne }+ \text { apelatywy }\end{array}$ & $\begin{array}{l}5 \\
4 \\
1\end{array}$ & $\begin{array}{l}1 \\
1 \\
0\end{array}$ & $\begin{array}{l}\mathbf{0} \\
0 \\
0\end{array}$ & $\begin{array}{l}\mathbf{0} \\
0 \\
0\end{array}$ \\
\hline $\begin{array}{l}\text { 2. Chrystus } \\
\text { onimy chrystologiczne }{ }^{9} \\
\text { onimy chrystologiczne }+ \text { apelatywy } \\
\text { onimy chrystologiczne }+ \text { antroponimy }+ \\
\text { apelatywy, w tym leksyka biblijna }\end{array}$ & $\begin{array}{l}74 \\
11 \\
50 \\
13\end{array}$ & $\begin{array}{l}4 \\
4 \\
0 \\
0\end{array}$ & $\begin{array}{l}\mathbf{0} \\
0 \\
0 \\
0\end{array}$ & $\begin{array}{l}1 \\
0 \\
0 \\
1\end{array}$ \\
\hline $\begin{array}{l}\text { 3. Maryja } \\
\text { onimy maryjne }{ }^{10} \\
\text { onimy maryjne }+ \text { apelatywy } \\
\text { onimy maryjne }+ \text { inne onimy }+ \\
\text { apelatywy, w tym leksyka biblijna }\end{array}$ & $\begin{array}{l}87 \\
25 \\
21 \\
41\end{array}$ & $\begin{array}{r}14 \\
14 \\
0 \\
0\end{array}$ & $\begin{array}{l}\mathbf{0} \\
0 \\
0 \\
0\end{array}$ & $\begin{array}{l}1 \\
0 \\
0 \\
1\end{array}$ \\
\hline
\end{tabular}

${ }^{6} \mathrm{~W}$ analizie nie brano pod uwagę odmian schematyzmów typu: św. Pawet Pierwszy Pustelnikśw. Pawet Eremita.

${ }^{7}$ Patrocinium, inaczej wezwanie, jest śladem obecności świętych w świątyniach. Określenie to wywodzi się z języka łacińskiego, w którym oznacza ‘opiekę, ochronę' (Dziewiątkowski 2002: 7; Kumor 2006: 73).

${ }^{8}$ Stanowią je określenia Trójcy Świętej, Ducha Świętego, przymiotów Bożych, np. Opatrzność (Mieczkowski i in. 2011: 278).

${ }^{9}$ Nazwy obejmują: określenia osobowe, np. Salwator, Święta Rodzina; dogmatyczne, np. Zmartwychwstanie, Boże Ciało, i ewangeliczne, np. Przemienienie, Krzyż Święty (Mieczkowski i in. 2011: 278).

${ }^{10}$ Nazwy obejmują: określenia dogmatyczne, np. Niepokalane Poczęcie NMP; ewangeliczne, np. Nawiedzenie NMP; dewocyjne, np. MB Różańcowa; związane z przywilejami maryjnymi, np. $M B$ Easkawa; nawiązujące do miejsc kultu, np. MB Częstochowska, i szczególnego orędownictwa, np. Królowa Korony Polskiej. Uwzględniono wariantywne nazwania Bożej Rodzicielki, m.in.: Matka Boża, Najświętsza Maryja Panna, Bogarodzica (Mieczkowski i in. 2011: 278). 


\begin{tabular}{|c|c|c|c|c|}
\hline \multirow{2}{*}{$\begin{array}{c}\text { Motywacja kulturowa nazw } \\
\text { z charakterystyką podstaw } \\
\text { leksykalnych }\end{array}$} & \multicolumn{4}{|c|}{ Typy chrematonimów } \\
\hline & ideonimy & patrocinia $^{7}$ & faleronimy & inne \\
\hline $\begin{array}{l}\text { 4. Aniołowie } \\
\text { onimy anielskie } \\
\text { onimy anielskie + apelatywy }\end{array}$ & $\begin{array}{l}2 \\
1 \\
1\end{array}$ & $\begin{array}{l}\mathbf{1} \\
1 \\
0\end{array}$ & $\begin{array}{l}\mathbf{0} \\
0 \\
0\end{array}$ & $\begin{array}{l}\mathbf{0} \\
0 \\
0\end{array}$ \\
\hline $\begin{array}{l}\text { 5. Święci i błogosławieni } \\
\text { hagionimy } \\
\text { hagionimy + apelatywy } \\
\text { hagionimy onimy świętych }+ \text { inne onimy }+ \\
\text { apelatywy } \\
\text { apelatywy związane ze scenami } \\
\text { z żywotów świętych }{ }^{11}\end{array}$ & $\begin{array}{r}156 \\
129 \\
20 \\
2 \\
\\
5\end{array}$ & $\begin{array}{r}23 \\
23 \\
0 \\
0 \\
0\end{array}$ & $\begin{array}{l}\mathbf{0} \\
0 \\
0 \\
0 \\
0\end{array}$ & $\begin{array}{l}\mathbf{0} \\
0 \\
0 \\
0\end{array}$ \\
\hline $\begin{array}{l}\text { 6. Kategorie mieszane } \\
\text { — trynitarno-anielska } \\
\text { onimy } \\
\text { onimy + apelatywy } \\
\text { — chrystologiczno-maryjna } \\
\text { onimy } \\
\text { onimy + apelatywy } \\
\text { — chrystologiczno-maryjno-hagionimiczna } \\
\text { onimy } \\
\text { onimy + apelatywy } \\
\text { — maryjno-hagionimiczna } \\
\text { onimy } \\
\text { onimy + apelatywy } \\
\text { — maryjno-hagionimiczno-anielska } \\
\text { onimy } \\
\text { onimy + apelatywy } \\
\text { — hagionimiczno-chrystologiczna } \\
\text { onimy } \\
\text { onimy + apelatywy }\end{array}$ & $\begin{array}{r}22 \\
\mathbf{1} \\
0 \\
1 \\
\mathbf{1 1} \\
3 \\
8 \\
2 \\
2 \\
0 \\
2 \\
3 \\
0 \\
3 \\
1 \\
1 \\
0 \\
1 \\
4 \\
2 \\
2\end{array}$ & $\begin{array}{l}\mathbf{2} \\
\mathbf{0} \\
0 \\
0 \\
\mathbf{1} \\
1 \\
0 \\
\mathbf{0} \\
0 \\
0 \\
\mathbf{0} \\
0 \\
0 \\
\mathbf{0} \\
0 \\
0 \\
\mathbf{1} \\
1 \\
0\end{array}$ & $\begin{array}{l}\mathbf{0} \\
\mathbf{0} \\
0 \\
0 \\
\mathbf{0} \\
0 \\
0 \\
\mathbf{0} \\
0 \\
0 \\
\mathbf{0} \\
0 \\
0 \\
\mathbf{0} \\
0 \\
0 \\
\mathbf{0} \\
0 \\
0\end{array}$ & $\begin{array}{l}\mathbf{0} \\
\mathbf{0} \\
0 \\
0 \\
\mathbf{0} \\
0 \\
0 \\
\mathbf{0} \\
0 \\
0 \\
\mathbf{0} \\
0 \\
0 \\
\mathbf{0} \\
0 \\
0 \\
\mathbf{0} \\
0 \\
0\end{array}$ \\
\hline $\begin{array}{l}\text { 7. Tradycja chrześcijańska } \\
\text { leksyka religijna }{ }^{12} \\
\text { onimy duchownych } \\
\text { onimy biblijne }+ \text { apelatywy }\end{array}$ & $\begin{array}{r}75 \\
63 \\
8 \\
4\end{array}$ & $\begin{array}{l}\mathbf{1} \\
1 \\
0 \\
0\end{array}$ & $\begin{array}{l}\mathbf{0} \\
0 \\
0 \\
0\end{array}$ & $\begin{array}{l}6 \\
6 \\
0 \\
0\end{array}$ \\
\hline
\end{tabular}

${ }^{11}$ Są to nazwy, w których nie pojawia się imię świętego lub błogosławionego, a które są ściśle związane z życiem poszczególnych postaci.

${ }^{12}$ Leksyka odnosząca się do terminologii i symboliki chrześcijańskiej, wyrazy związane historycznie $\mathrm{z}$ wiarą $\mathrm{i}$ obrzędami religijnymi. 


\begin{tabular}{|c|c|c|c|c|}
\hline \multirow{2}{*}{$\begin{array}{c}\text { Motywacja kulturowa nazw } \\
\text { z charakterystyką podstaw } \\
\text { leksykalnych }^{6}\end{array}$} & \multicolumn{4}{|c|}{ Typy chrematonimów } \\
\hline & ideonimy & patrocinia $^{7}$ & faleronimy & inne \\
\hline $\begin{array}{l}\text { 8. Historia Cudownego Obrazu, } \\
\text { sanktuarium i/lub kraju } \\
\text { onimy niekonsekrowanych osób świeckich } \\
\text { lub duchownych } \\
\text { onimy osób niekonsekrowanych + apelaty- } \\
\text { wy } \\
\text { chrematonim + apelatywy } \\
\text { chrematonim + inne onimy + apelatywy } \\
\text { etnonim + apelatywy } \\
\text { apelatywy }\end{array}$ & $\begin{array}{l}1 \\
4 \\
1 \\
3\end{array}$ & $\begin{array}{l}0 \\
0 \\
0 \\
0\end{array}$ & $\begin{array}{l}0 \\
0 \\
0 \\
0\end{array}$ & $\begin{array}{l}14 \\
10\end{array}$ \\
\hline $\begin{array}{l}\text { 9. Lokalizacja, przeznaczenie obiektów, ich } \\
\text { charakterystyka } \\
\text { oronim } \\
\text { antroponim + apelatywy } \\
\text { apelatywy }\end{array}$ & $\begin{array}{l}1 \\
0 \\
0 \\
1\end{array}$ & $\begin{array}{l}\mathbf{0} \\
0 \\
0 \\
0\end{array}$ & $\begin{array}{l}1 \\
0 \\
0 \\
1\end{array}$ & $\begin{array}{r}20 \\
1 \\
1 \\
18\end{array}$ \\
\hline
\end{tabular}

\section{LITERATURA}

Badyda E. 2011: O problemach z ustaleniem postaci chrematonimu - na przyktadzie nazw polskich wyrobów cukierniczych, [w:] M. Biolik, J. Duma (red.), Chrematonimia jako fenomen wspótczesności, Wyd. UWM, Olsztyn, s. 31-42.

Bar J. 1999: Polscy święci, Wyd. ATK, Kraków.

Braun J. 1977: Częstochowa. Urbanistyka i architektura, Arkady, Warszawa.

Cieślikowa A. 1994: O motywacji w onomastyce, „Polonica” XVI, s. 193-199.

Dziewiątkowski J. A. 2002: Analiza onomastyczno-językowa wezwań kościołów $i$ kaplic $w$ archidiecezji gnieźnieńskiej, Wyd. Archidiecezji Gnieźnieńskiej, Gniezno.

Gałkowski A. 2008: Chrematonimy w funkcji kulturowo-użytkowej. Onomastyczne studium porównawcze na materiale polskim, włoskim, francuskim, Wyd. UŁ, Łódź.

Handke K. 1997: Stosunek użytkowników do nazewnictwa miejskiego, [w:] taż, Rozważania i analizy językoznawcze, Slawistyczny Ośrodek Wydawniczy, Warszawa, s. 445-454.

Kumor J. 2006: Wezwania kościołów parafialnych oraz parafii (archi)diecezji lubelskiej w latach 1805-2005, „Teka Komisji Historycznej Lubelskiego Oddz. PAN” 1, s. 72-98.

ks. Mieczkowski J., ks. Gilski M., ks. Cholewa M. 2011: Hierarchia prawd a patroni kościołów, „Liturgia Sacra” XVII, nr 2, s. 273-283.

Rozanow Z., Smulikowska E. 2009: Zabytki sztuki Jasnej Góry. Architektura. Rzeźba. Malarstwo, Śląskie Centrum Dziedzictwa Kulturowego w Katowicach, Katowice. 


\section{CHREMATONYMY OF JASNA GÓRA MONASTERY AND ITS CULTURAL BACKGROUND}

\section{SUMMARY}

The subject of the paper is the description of proper nouns denoting different objects located in Jasna Góra Monastery of the Pauline Order in Częstochowa. Nomina propria refer to the buildings, including their external (basilica, bastions, gates, museums, buildings, bells) and internal (porches, chapels, halls) elements and also to such objects as high altars and bye-altars, sculptures, wall paintings and easel paintings, cycles of polychrome on wall and vault paintings and medallions. The discussed chrematonyms include, among others, patrocinia, hagionyms, ideonyms, teonyms. Taking into consideration a motivation aspect, the analyzed proper nouns can be generally divided into two groups. The first one are the names directly connected with the sphere of the sacred, formed from onyms of different provenance (e.g. the persons of the Trinity, Mary, the Bible, names of saints and blesseds, including patron saints of Poland, distinguished brethren of the Pauline Order, priors of Jasna Góra Monastery) and derived from common names (e.g. connected with the scenes from the lives of saints and blessed, Marian symbols). The second group are the names not directly connected with the sphere of the sacred derived from onyms (e.g. names of lay founders of different objects in the sanctuary complex) and common names connected with the history of the foundation of the monastery and its history, including the siege of Jasna Góra by the Swedes in 1655 or location of designates. The article was written from a diachronic perspective which allowed for the inclusion of the original names of some objects. Therefore, in the onomastic and cultural analysis the variations of the names were included, such as, chapel of the Jabłonowski family/ Holy Guardian Angels, Sacred Heart of Jesus/Our Lady of Kodeń.

Key w ord s: chrematonym, hagionym, ideonym, patrocinium, teonym 